\title{
The United States Legal System: The Jurisprudence of Partisanship With Supreme Court Rulings
}

\author{
O Sistema Jurídico dos Estados Unidos: a Jurisprudência do \\ Partidarismo com as decisões da Suprema Corte
}

Shaurya Pathak

Pratyush Muthukumar ${ }^{1}$

\begin{abstract}
:
The current state of jurisprudence on legal precedent in the global setting, specifically within United States legal system, the case study for this article, is morphing to a cynical view of the partisanship within the court that judges the "supreme law of the land" - the Supreme Court. Rhetorical analysis of Supreme Court practices is altering from the view of holistic decisions by justices to an assumption of partisan bias, or "politically constructed bounds," that justices are subject to, willingly or unwillingly, due to the nature of the position. Though portrayed as a ruling unaltered by partiality from membership in a partisan body, and instead solely outlined by the Constitution of the United States with a duty of upholding the integrity of the document, a judge's role is not as unquestionable. Due to this, it is evident that political parties heavily influence the rulings and thus, precedents of future, past, and present. We analyze the effects of affiliations with a political party on a bipartisan scale-with the common agglomerations of Supreme Court rulings. We also analyzed ruling trends based on a judge's subjective beliefs and deviations from each judge's judgment when ruling on these cases. We have also devised a metric which calculates the probability of a judge deviating from his political party's belief and the effects of their belief on their rulings. Future studies will be able to expand on this topic by using the metric as a method of predicting rulings based on a probability matrix, and an analyzer of the average bias of the justices based on a given time period.
\end{abstract}

\section{KEYWORDS:}

Constitutional theory development; jurisprudence; partisanship; precedence.

\section{RESUMO:}

O estado atual da jurisprudência sobre precedentes legais no cenário global, especificamente no sistema jurídico dos Estados Unidos, está se transformando em uma visão crítica do partidarismo no tribunal que julga a "lei suprema da terra" - o Tribunal Supremo. A análise retórica das práticas da Suprema Corte está mudando a visão das decisões holísticas dos juízes para uma suposição de viés partidário, ou de "limites politicamente construídos", aos quais os juízes estão sujeitos, de boa ou má vontade, devido à natureza da posição. Embora seja retratado como uma decisão inalterada pela parcialidade da participação em um órgão partidário, e apenas delineada pela Constituição dos Estados Unidos com o dever de manter a integridade do documento, o papel de um juiz não é tão inquestionável. Devido a isso, é evidente que os partidos políticos influenciam fortemente as decisões e, portanto, os precedentes do futuro, passado e presente. Analisamos, neste estudo de caso, os efeitos de afiliações com um partido

\footnotetext{
${ }^{1}$ Cal State LA. Estados Unidos da América do Norte
} 
político em uma escala bipartidária - com as aglomerações comuns de decisões da Suprema Corte. Também analisamos as tendências de decisão com base nas crenças subjetivas de um juiz e nos desvios do julgamento de cada juiz ao decidir sobre esses casos. Criamos uma métrica que calcula a probabilidade de um juiz se desviar da crença de seu partido político e os efeitos dessa crença em suas decisões. Estudos futuros poderão expandir esse tópico usando a métrica como um método de previsão de decisões com base em uma matriz de probabilidade e um analisador do viés médio dos juízes com base em um determinado período de tempo.

\section{PALAVRAS-CHAVE:}

Desenvolvimento da Teoria Constitucional; Jurisprudência; Partidarismo; Precedência.

\section{INTRODUCTION}

Multiple models have been established attempting to quantify the bias applied to a justice's ruling based off multiple approaches such as an attitudinal ${ }^{2}$, strategic $^{3}$ and an analytical ${ }^{4}$ approach to explaining judicial decision making. Some have even attempted to establish prediction models in as early as $1963^{5}$. The FantacySCOTUS study successfully concluded that humans were not sufficient in predicting cases with empirical evidence finding that the median human guessed at 50\% accuracy and the top predictors were at $75 \%$.

This paper will identify the rhetorical situation which is present in the partisanship in the courts of the United States legal system, specifically the exigence, constraints, and audience present within this twenty-first-century dilemma. This will include the media's interpretation of the rulings of justices, the explanation of temporal focus in the early 21 st century regarding case law, narratives, the ruling party, Supreme Court nominations, etc. The paper will also establish a discernable pattern of rulings from judges based on a probability matrix metric trained by an artificial neural network to accurately predict the political biases of Supreme Court

\footnotetext{
${ }^{2}$ See "The Supreme Court and the Attitudinal Model Revisited" (Jeffrey A. Segal \& Harold J. Spaeth, STAFFING THE COURT, pp. 178-222).

${ }^{3}$ See "Overriding Supreme Court Statutory Interpretation Decisions" (William N. Eskridge, THE YALE LAW JOURNAL, vol. 101, no. 2, 1991) and "The Choices Justices Make" (Lee Epstein and Jack Knight, CONGRESSIONAL QUARTERLY PRESS, 1998).

4 "The Median Justice On The United States Supreme Court" (Andrew D. Martin and Kevin M. Quinn, NORTH CAROLINA LAW REVIEW, 2004).

5 "What Computers Can Do: Analysis and Prediction of Judicial Decisions" (Reed C. Lawlor, AMERICAN BAR ASSOCIATION JOURNAL, 1963)
} 
justices. Finally, a conclusion will be made upon the effect the ruling party has upon the legal the precedent set by the highest court of the law-the Supreme Court.

A thorough analysis of media will subjectively ${ }^{6}$ quantify the proceedings of 5 Supreme Court hearings. Observations of a shift in the view of rulings as holistic to a more politicallycharged move will be thoroughly analyzed. In order to view the shift, an explanation of the forms of the proof present will be examined further. A discussion based on ruling histories and on the ability to quantify such a ruling either objectively or subjectively will reveal that indeed, such a discernable pattern is evident.

We will include a step-by-step analysis of the methodologies of the probability matrix metric. This will use analysis of research and data used for the training of the probability matrix metric through a simple view of the algorithms that allow for the metric to function effectively and accurately. Predictions and testing of the probability metric including but not limited to the early 21 st century will be conducted.

\section{SELECTED TEXTS MEDIA ANALYSIS}

\section{Human Based Modeling}

This is a case where the majority performed below the null; in this study, only casebased decisions were recorded and humans underperformed the null by $16 \%$. The Fantasy SCOTUS study successfully concluded that humans were not sufficient in predicting cases with empirical evidence finding that the median human guessed at 50\% accuracy and the top predictors were at $75 \%{ }^{7}$. Although many feel as if Supreme Court decisions are foretold due to their biases, the experiential learning and research require far more than a casual follower of

\footnotetext{
${ }^{6}$ Herein, we refer to a subjective quantification as a selective choice of exclusively relevant case details and partisan bias indicators, not to be mistaken with a non-objective method of quantification. The subjectivity lies within the selection of input vectors, not the result of the algorithm, which remains objective.

${ }^{7}$ See "Fantasy SCOTUS: Crowdsourcing a Prediction Market for the Supreme Court" (Aft Blackman and Corey Carpenter, NORTHWESTERN JOURNAL OF TECHNOLOGY AND INTELLECTUAL PROPERTY, vol. 10, 2012).
} 
the Supreme Court to predict the outcomes of such cases. However, the top experts in the field of partisan politics and judicial evolution who closely analyze Supreme Court ruling trends can outperform the null by 9 percent.

\section{COMPUTER-BASED MODELING}

Prior to judging models, we must define a null in which we judge the approaches. The null will be determined by a moving average of the justice's decisions ${ }^{8}$. This will use M known as "a common hyper-parameter," the optimization of this variable quantifies the amount of past useful for the prognostication of the future. The null will set the $M$ at 10 where it sets a "prior decade" ${ }^{\prime 9}$ baseline. This null leads to a $66.2 \%$ Justice prediction accuracy and a $67.5 \%$ case level accuracy.

Multiple models have been established attempting to quantify the bias applied to a justice's ruling based off multiple approaches such as an attitudinal, strategic and an analytical approach to explaining judicial decision making. Some have even attempted to establish prediction models in as early as 1963. The most renowned computer-based model for detailing political party bias is the Martin-Quinn Score which uses a dynamic model ${ }^{10}$, identifying cases as either favorable for a Republican or favorable for a Democrat ${ }^{11}$. As of 2017, TABLE 1 below illustrates the current landscape ${ }^{12}$ of political bias within the Supreme Court. As the scores go higher the Supreme Court Justices are identified as more conservative and as the scores go lower on the negative side. Justice Kennedy has been unbiased and as a result of that has become the median justice for the past 5 years on this model, making him the most powerful justice in the current term.

\footnotetext{
${ }^{8}$ See "A General Approach for Predicting the Behavior of the Supreme Court of the United States" (Daniel Martin Katz, et al., PLoS ONE, vol. 12, no. 4, 2016).

${ }^{9}$ Cit. supra, note 13 .

${ }^{10}$ Herein, "dynamic model" referrs to the Martin-Quinn Scores that reflect a smooth judicial trend through time, by pivoting on crucial identifiers, including the "judicial" median or the "location of each case in the policy space". "Martin-Quinn Scores", (Andrew D. Martin and Kevin M. Quinn, LSA UMICH.edu, 2017).

${ }^{11}$ For simplicity and argument's sake, we annul cases of independent or no party affiliation, and concentrate on a conservative-liberal spectrum to place selected justices pertaining to timeframes.

${ }^{12}$ Herein, the current landscape refers to the time period in which the data was collected, in this instance being October 2017, and thusly does not reflect any changes since Martin \& Quinn recorded data for TABLE 1.
} 
TABLE 1

\begin{tabular}{llr}
\hline \hline & & Mean Score \\
\hline Justice Name & AMKennedy & 0.426 \\
& CThomas & 3.113 \\
& EKagan & -1.605 \\
& JGRoberts & 0.429 \\
& NMGorsuch & 1.215 \\
& RBGinsburg & -2.734 \\
SAAlito & 2.184 \\
SGBreyer & -1.675 \\
& SSotomayor & -3.222 \\
\hline
\end{tabular}

FIGURE 1 shows all Supreme Court justice along with the median justice for all periods from 1947.

FIGURE 1

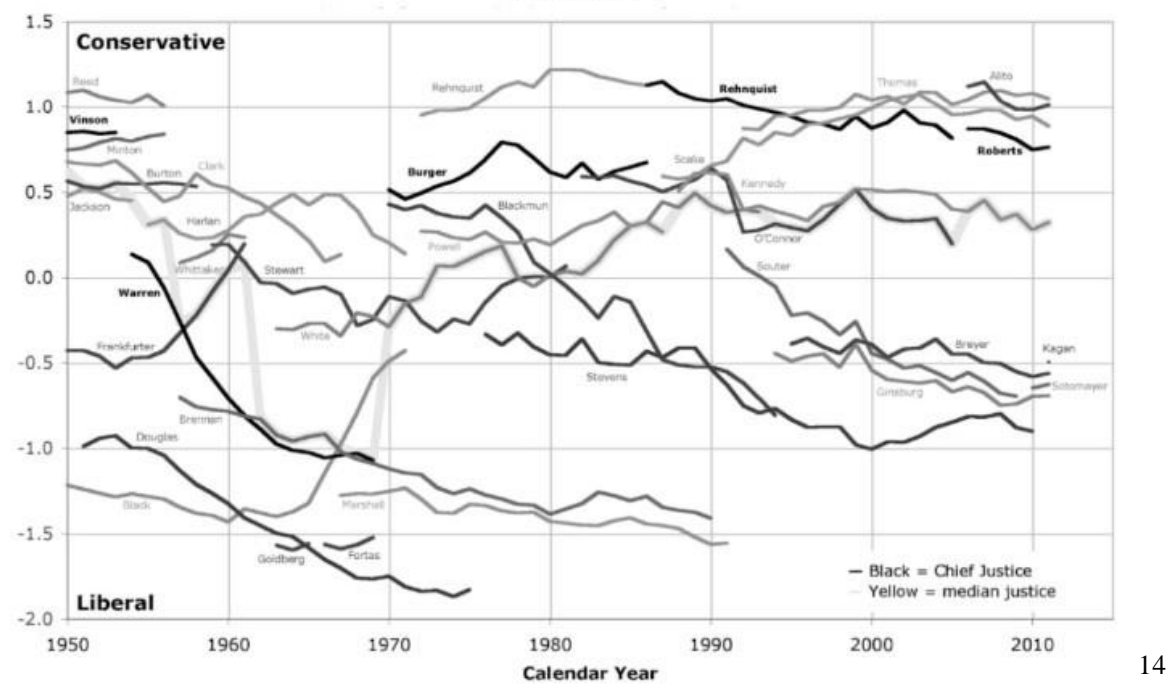

Another model had attempted to predict complete cases and specific justice predictions ${ }^{15}$. Using a combination of python and machine learning Katz had established a

\footnotetext{
${ }^{13}$ Data for TABLE 1 is supplied from the Martin-Quinn Scores, cit. supra, note 9, following similar organizational patterns to determine partisanship within current Supreme Court justices.

${ }^{14}$ Data for FIGURE 1 is sourced from a 2013 scholarly journal data sheet from Professor Michael A. Bailey of Georgetown University.

${ }^{15}$ Cit. Supra, note 14.
} 
model which was able to predict the decisions of judges with an accuracy of $71.9 \%$ at the justice level and $70.2 \%$ when predicting cases. While these results may be significantly higher than simply flipping a coin and higher than most humans would be able to predict as defined by the FantasySCOTUS blog. Here we must reintroduce the null created in the same study alone where the Justice prediction accuracy was $66.2 \%$ and the case level accuracy was at $67.5 \%$. Using this null we can conclude that at best we can only consistently predict the outcomes of the Supreme Court 5 percent better than simply guessing ${ }^{16}$.

\section{JUDICIAL DOCUMENT REVIEW}

The bias presence has been well known and documented by only investigators but known by judges to "operate-- within politically constructed bounds" ${ }^{17}$. Late Justice Scalia famously stated that all judges are ultimately all "politically partisan" ${ }^{18}$. Some Supreme Court Justices don't attempt to hide their political bias with Ruth Bader Ginsburg publicly criticizing Donald Trump and taking a side in the controversial Colin Kaepernick incident. ${ }^{19}$

The landmark cases of Abood v. Detroit ${ }^{20}$ and the corresponding later overturning of such case in the trial proceedings of Janus v. AFSCME ${ }^{21}$ are prime examples of the existent bias in Supreme Courts. Abood v. Detroit was a precedent initiating case in the Supreme Court where judges had ruled that continued establishment of a union shop did not violate either the first amendment ${ }^{22}$ or the fourth amendment ${ }^{23}$. The Court adjudicated a decision based upon the

\footnotetext{
${ }^{16}$ Herein, the methodology behind "simply guessing" remains to be an objective stochastic selection of randomized outcomes, where little to no reasoning was argued for such a selection made by an individual knowledgeable with politics available through the general populous in a limited amount.

17 See "Law and Legitimacy in the Supreme Court" (Richard H. Fallon, THE BELKNAP HARVARD UNIVERSITY PRESS, 2018).

${ }^{18}$ See "Supremely Partisan" (James D. Zirin, ROWMAN AND LITTLEFIELD PUBLISHERS, 2016)

${ }^{19}$ See "The Federal Judiciary: Strengths and Weaknesses" (Richard A. Posner, THE HARVARD UNIVERSITY PRESS, 2017).

${ }^{20}$ See Abood v. Detroit Bd. of Ed., 431 U.S. 209, 97 S. Ct. 1782, 52 L. Ed. 2d 261 (1977).

${ }^{21}$ See “Janus v. AMERICAN FEDERATION OF STATE", 138 S. Ct. 2448, 585 U.S., 201 L. Ed. 2 d 924 (2018).

${ }^{22}$ See U.S. Const. amend. I.

${ }^{23}$ See U.S. Const. amend. IV.
} 
cases Railway Employees' Dept. v. Hanson ${ }^{24}$, and International Ass'n of Machinists v. Street ${ }^{25}$. In Railway Employees' Dept. v. Hanson and International Ass'n of Machinists v. Street, the Court ruled that the prevention of "free-riding," 26 or reaping the benefits of a union without contributing to said union, was a reasonable ground in the inclusion of agency shop clauses in collective bargaining agreements. On these grounds, in a 9-0 unanimous vote, the Court voted to uphold union participation to be mandatory in the public sector.

Later, the opportunity was set to overturn Abood v. Detroit Board of Education ${ }^{27}$ in the case Friedrichs v. California Teachers Ass' ${ }^{28}$, which was ready to be overturned, however, a 4-4 deadlock occurred due to the passing of Justice Antonin Scalia. However, the arguments which were used in this case still concurrently apply to future cases. The anti-union fees party declared that the law should be overruled notwithstanding stare decisis ${ }^{29}$ due to the violation of the first amendment. The pro-union fees party declared the lack of mandatory fees would encourage the act of free-riding. As previously stated, however, this deadlock resulted in the Abood v. Detroit Board of Education ruling standing.

In the case of Janus v. AFSCME ${ }^{30}$, the Abood v. Detroit Board of Education ruling was overturned in a 5-4 split vote. The reasoning behind the overruling is that the first amendment in Abood v. Detroit Board of Education ${ }^{31}$ was wrongly decided. Samuel Alito had cited the recent majority opinions in Knox v. SEIU ${ }^{32}$ and Harris v. Quinn ${ }^{33}$ in recent precedent-setting cases. The liberal party had warned during these cases that Samuel Alito had swayed these cases with intent to overturn the decision of Abood v. Detroit Board of Education. Along with this Samuel Alito had also pledged that he would be faithful to the previous setting precedent and would not break this precedent. This is one of the prime examples of partisan bias as Samuel

\footnotetext{
${ }^{24}$ See Railway Employes v. Hanson, 351 U.S. 225, 76 S. Ct. 714, 100 L. Ed. 1112 (1956).

${ }^{25}$ See Intern. Ass'n of Machinists v. Org'n of Petroleum, 477 F. Supp. 553 (C.D. Cal. 1979).

${ }^{26}$ Refers to the concept of recieving the benefits of a union without contributing to the union. This is detrimental to the union as it does not recieve sufficient funding, leading to the argument on whether it should be required.

${ }^{27}$ Cit. supra, note 26

${ }^{28}$ See "Friedrichs v. California Teachers Ass'n", 136 S. Ct. 2545 (U.S. 2016).

${ }^{29}$ Herein, we standby the Latin and judicial definition for stare decisis as to "stand by things decided" or adjudication by upholding previous precedent

${ }^{30}$ Cit. supra note, 26.

${ }^{31}$ Cit. supra note, 25.

${ }^{32}$ See “Knox v. Service Employees Intern. Union”, 132 S. Ct. 2277, 567 U.S. 298, 183 L. Ed. 2 d 281 (2012).

${ }^{33}$ See "Harris v. Quinn", 134 S. Ct. 2618, 573 U.S., 189 L. Ed. 2 d 620 (2014).
} 
Alito had changed 3 cases and had gone against his pledge to precedent for the purpose of winning a landmark case for his political party.

Trump v. Hawaii ${ }^{34}$ is a landmark case that defines a majority of the cases conducted by the Supreme Court. Only differing from the rest in the national media coverage which it received. In this well known case Donald Trump, the 45th President of The United States, had issued a 90 day travel ban on immigrants from the countries of Iran, Libya, Somalia, Syria, Yemen, North Korea, and Venezuela with Chad, Iraq, and Sudan were removed from the preliminary drafting of the executive order.

Almost all national media news coverage had covered the issue ${ }^{35}$ and pressure was on the Justices to make their decisions. With the peak amount of pressure, these justices will face in their decision making all 9 justices reverted to their political beliefs which the world expected. The political party bias is exemplified due to the realization that when there are 5-4 justices the most prominent pattern ${ }^{36}$, is Sotomayor, Kagan, Ginsburg, and Breyer voting on one side while Roberts, Kavanaugh, Alito, Gorsuch, and Thomas voting on the other side.

\section{PROBABILITY MATRIX METRIC}

To more precisely envisage the future state of the partisanship within the American justice system, we developed a probability metric using an artificial algorithm to conjecture a prediction on a particular ruling given a thorough knowledge of the case. For the past four decades, scholars have mulled over the possibility of combining two such disparate fields such as computer science and law to amalgamate into a future of smarter, more impartial rulings. The pioneering works of the TAXMAN experiments conducted in the late 1970s, though seeking to accurately predict legal implications on taxation of corporate reorganizations, proved

\footnotetext{
${ }^{34}$ See “Trump v. Hawaii”, 138 S. Ct. 2392, 585 U.S., 201 L. Ed. 2 d 775 (2018).

${ }^{35}$ News media coverage of the Trump v Hawaii case spans media from the ideological partisan spectrum, including the New York Times, CNN, NBC, NPR, etc

${ }^{36}$ See "The Supreme Court Database" (Harold J. Spaeth, Lee Epstein, et al., 2018).
} 
to lay a foundation for a more discrete methodology of looking at judicial process ${ }^{37}$. These distinct legal concepts, described as Methods of Philosophy, rather than Methods of Sociology, were imbued into later works more than a decade later on automating legal services through a more cost/benefit analysis approach, which revolved around an ideal "predictive expert system with reasonably accurate predictors" mitigating disputes "voluntarily...quickly...[and] void of costly litigation". 38

After advances in civil litigation began rapidly expanding with the cynical views of emoluments for legal professionals tasked to a client's case, a similar approach was tried on criminal cases. At this time period, at the close of the 20th century, artificial intelligence's involvement in legal proceedings shifted to a more beneficent role, at the cost of a bigger stake in the livelihoods of defendants and litigants. Perhaps the most extensive upside to artificial intelligence in the law field is the ability to drastically minimize the time and expenses of such a lengthy legal battle 39 to "better understand, evaluate, and disseminate decisions." Around the similar time period of such a utility shift in artificial intelligence in the legal setting, the "jurisprudential rigor and legal reasoning" of algorithmic adjudication is called into question, specifically the disregard from "cognoscenti fields" resulting in a lack of expert systems with a "high heuristic content," thus stipulating the need for a flexible and transparent machine ${ }^{40}$. Current evaluations of artificial intelligence technology place expert systems as "pervasive and consequential, yet lacking oversight" ${ }^{\prime 1}$. To ensure full autonomy within 40 decision-making technology, a more procedural normalized detection approach is necessary. The key to such fluid oversight of adjudication technology stems from the field of big data. With large scale data collection in the magnitude of tens of thousands to millions of data points, we can ensure a systematic approach to each individualized case.

\footnotetext{
${ }^{37}$ The TAXMAN experiments "clarif[ied] the structures of law modeled and provided a theory for legal concepts." See "Reflections on TAXMAN: An Experiment in Artificial Intelligence and Legal Reasoning", L. Thorne McCarty (HARVARD LAW REVIEW, pp. 837).

${ }^{38}$ See "The Potential of Artificial Intelligence to Help Solve the Crisis in our Legal System", Donald H. Berman, Carole D. Hafner (COMMUNICATIONS OF THE ACM, pp. 928).

${ }^{39}$ In reality, decisions are made under "severe pressures of limited time, money, and information", cit. supra, note 27, (Donald H. Berman, et. al, pp. 929).

${ }^{40}$ See "Expert Systems in Law: A Jurisprudential Approach to Artificial Intelligence and Legal Reasoning", Richard E. Susskind (THE MODERN LAW REVIEW, pp. 192)

${ }^{41}$ See "The Scored Society: Due Process for Automated Predictions" (Danielle Keats Citron \& Frank Pasquale, pp. 89).
} 
Recent advancements in a form of algorithm structure called ratio decidendi ${ }^{42}$ open the door for artificial intelligence to enter the legal sphere. Ratio decidendi ${ }^{43}$ mimics the rationalizing portions of a human brain and creates a structure that allows for a machine learning algorithm to rationalize these decisions. This research is particularly useful when there is a precedent before the decision. In that case, the algorithm can rationalize the precedent's decision and implement the results into its own decision. Similar to a flow chart diagram, the algorithm walks through each result and its consequences and determines which would be the choice that would benefit the greater good. However, in these types of structures, where cases may not exactly line up with previous precedents, or be blatantly the opposite, the algorithm tends to leave out the minority. This is a large problem, as these types of algorithms will be used for the newly made California bail elimination law. With these types of algorithms, we will see the minority populations being subjected to harsher treatment. In this sense, even the most sophisticated attempts at rationalizing the decisions made will result in us indirectly programming racism into our algorithms ${ }^{44}$. This research pushed us to pursue a purely quantitative and blind algorithm ${ }^{45}$, as to use only the facts of the case to arrive at a decision. Any other methodologies of approaching case data would only result in blatant racism being programmed into the artificial neural network.

For our probability matrix, we commenced by intricately examining the dataset we used to train our model. With a 2.9 million data point database from the Supreme Court Database, we used Python imaging tools ${ }^{46}$ to grasp a more cognizant perspective on previous Supreme Court data. Our first test was to see the configurations between the matchups of petitioners and respondents for cases from 1791 to 2017, with each case having 247 additional units of

\footnotetext{
${ }^{42}$ See "A Computational Model of Ratio Decidendi”, (L. Karl Branting, ARTIFICIAL INTELLIGENCE AND LAW, pp.1-31),1994.

${ }^{43}$ Herein, though closely related to the original definition, we refer to ratio decidendi as the algorithm developed by L. Karl Branting, not to be mistaken for the traditional latin and judicial definition of ratio decidendi, "the reason" or "the rationale for the decision"

${ }^{44}$ Herein lies a discussion on an analysis into Edward Lorenz' Chaos Theory. Though derived in 1961, modern technology disregarding artificial intelligence seems to be obeying the axiom. Artificial intelligence, rapidly progressing further than Moore's Law observations of circuit board transistors, may break the boundaries of chaos theory, essentially deprogramming racism from such ratio decidendi algorithms.

${ }^{45}$ An alternative redefinition of "purely quantitative and blind" can similarly span to a wholly objective analysis of Supreme Court case data in the 21st century.

${ }^{46}$ The Python imaging tools include numpy for linear algebra calculation, pandas for time series indexing, and matplotlib.pyplot for graphing utility.
} 
supplemental information pertaining to the petitioner and respondent ${ }^{47}$. The first analysis of the dataset was a scatterplot of petitioners and respondents. From FIGURE 2, we can see that there is a high concentration of Supreme Court cases in the 100-200 block of petitioner-respondent interactions. As per the Supreme Court Database Codebook, the respective parties are majority corporate entities. $^{48}$

\section{FIGURE 2}

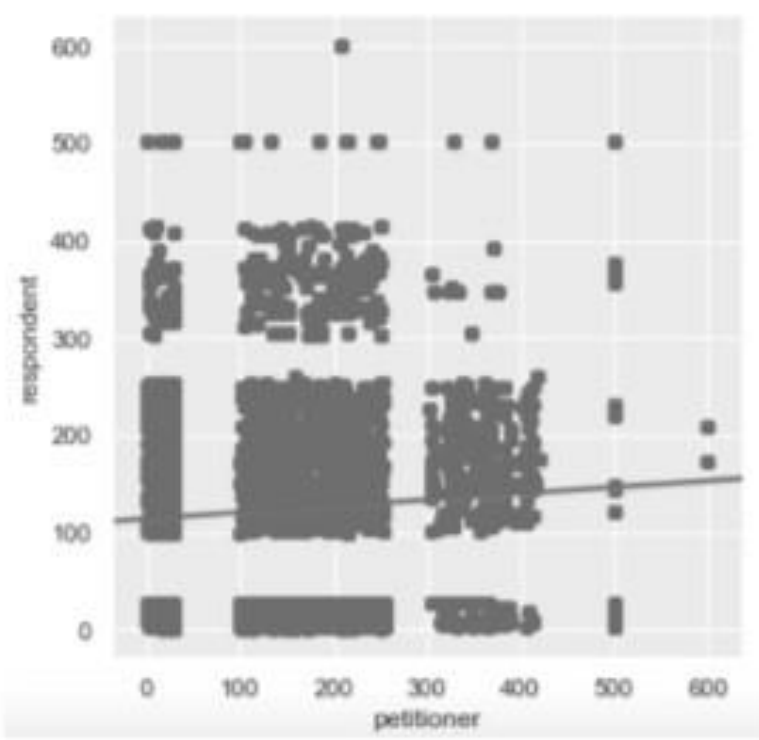

49

Furthermore, we sought to quantify the correlations between the dependent variable, the winning party, and all other independent variables. Using a correlation matrix as found in FIGURE 3, we can prioritize lightly shaded coordinates as those with high positive correlation, while extremely dark shaded coordinates as those with high negative correlations, and further ignore those that are standardly shaded, as they show no correlations.

\footnotetext{
${ }^{47}$ Our dataset was sourced by the Washington University Law School Supreme Court Database. Cit. supra. Note 27.

48 The Supreme Court Database Codebook refers to demarcations as "inductively created, with petitioner and respondent characterized as the Court's opinion identifies them." Cit. supra, note 37.

${ }^{49}$ Data for FIGURE 2 was calculated through a matplotlib.pyplot scatter plot accounting for the two-variable relationship of petitioner and respondent, where axes demarcations correspond to the Supreme Court Codebook terminology for labeling of input features.
} 


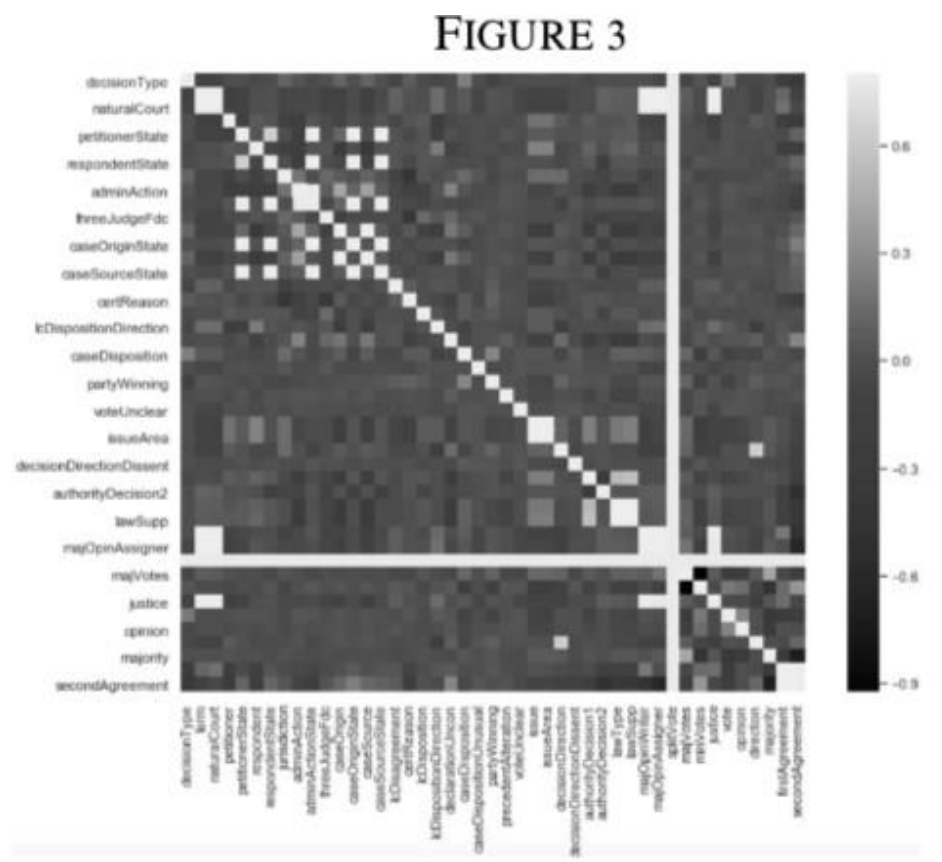

We extrapolated on the most highly correlated inputs to our dependent variable, which include decision type, jurisdiction, direction ${ }^{51}$, opinion, case disposition, majority votes, and issue. To more intricately look at the specific relative importance of these select features on the dependent variable, we employed an array of pair plots to study the behavior of the top eight most correlated inputs, which is exemplified in FIGURE 4.

\footnotetext{
${ }^{50}$ We used a seaborn correlation matrix to identify correlations of pairs of input vectors by standardizing inputs with the Normal Equation for linear regression and plotting hue coordinates.

${ }^{51}$ Herein, direction refers to the ideological partisan perspectives of the ruling. For example, a Supreme Court ruling that immediately results in a Democratically-controlled Senate is categorized as a Democratic direction.
} 


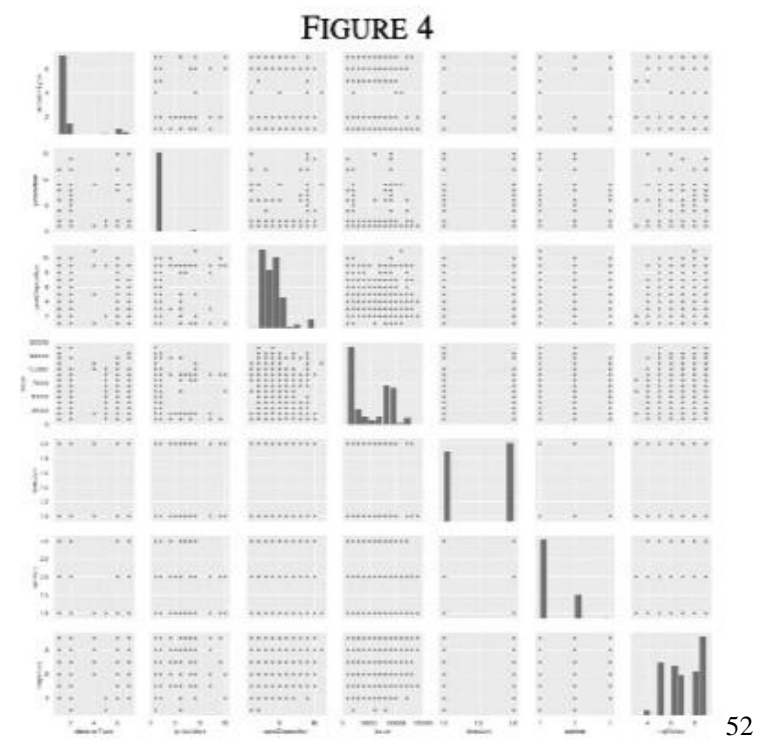

Our final interpretation of the data was to look at the dependent variable in more depth. To do so we aggregated the average direction of Supreme Court justices by decade and plotted them on a split line graph. Values in FIGURE 5 that are above the non-partisan line are those that are historically conservative-leaning, while those below are historically liberal-leaning.

\section{FIGURE 5}

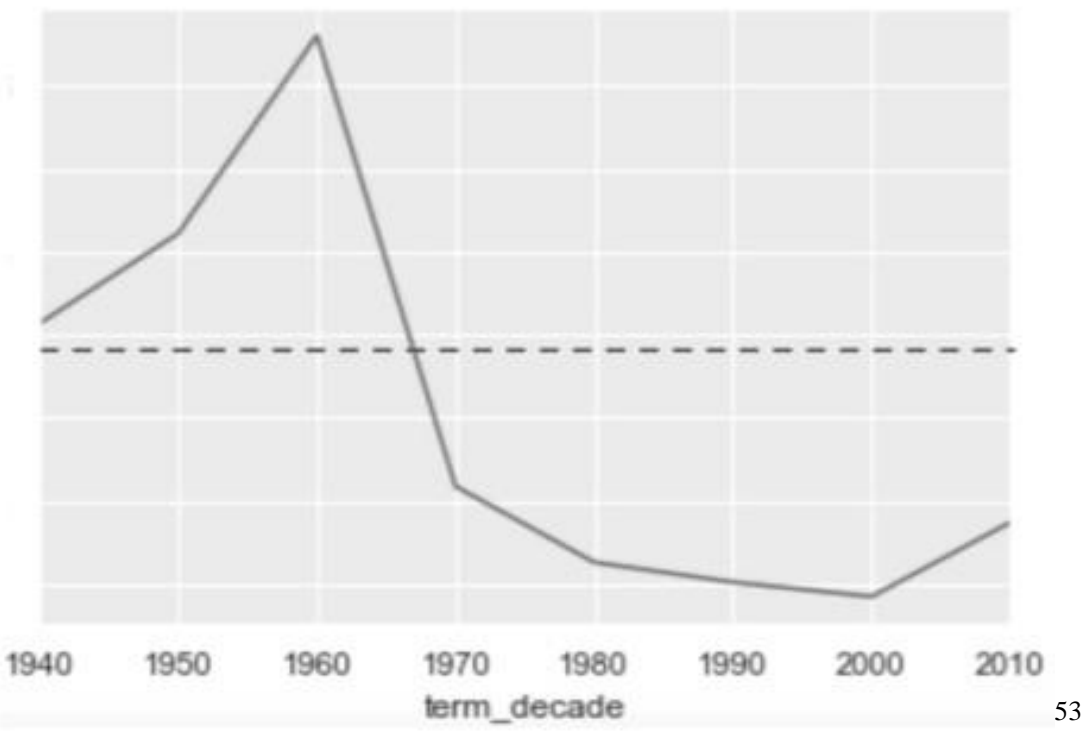

\footnotetext{
${ }^{52}$ We utilized numpy pair plots to individually analyze two-variable relationships of non-categorical numerical variables.

${ }^{53}$ We used an aggregate function to group historical direction data by decade followed by linear regression. Cit. supra, note 46 regarding definition of "direction".
} 
In our study, we utilized the Supreme Court Database populated with 2.9 million data points on various facets of 21st century Supreme Court cases. This database passed through our custom-built artificial neural network, the computer equivalent of a human brain that enables a computer system to "learn" similarly to a human ${ }^{54}$. Through a process called K-fold cross validation $^{55}$, the entire set is split into two major sets, the training set and the test set. Within these sets, there are a k-multiple amount of smaller datasets that allow for a more streamlined process of information input. The data is then split into dependent and independent variable clusters $^{56}$, where the independent variables are used to predict the outcome of the dependent variable. In this scenario, there were a total of 33 independent variable clusters, some of which included fields such as precedent alteration, case disposition, jurisdiction, petitioner state, etc. The dependent variable was the winning party, which would be predicted by the 2.6 million data points corresponding to 33 subfields. Note that standard data preprocessing methods were followed $^{57}$, including dummy variable normalization, feature scaling, and null value deletion.

Due to the numerous similarities that artificial neural networks have with the human brain, one can visualize an expert system as such to work as a traditional human brain: a set of synapses are connected to a set of nodes, that in turn pass signals not unlike a baton race from one node to the next. In this system, the exact moment of the "pass of the baton" 58 happens through a function so named an activation function. The activation function can drastically affect the outcome of the neural network, and in this case, a linear activation function was used, meaning that since the output of the system is binary, either petitioner or respondent victory, a linear activation function would result in an output that is one of two options.

The final portion of the neural network revolves around further partitioning of the dataset. Each dataset of both the test and training set is split into 100 batches, termed epochs, which was parsed through a quad-core Intel i5 processor, resulting in an accuracy of $87.65 \%$. Essentially, if one were to pass through a case briefing with necessary information as outlined

\footnotetext{
${ }^{54}$ See "Human brain and human learning", (LA Hart and Leslie A. Hart, LONGMAN, 1983).

${ }^{55}$ See "Neural Network Ensembles, Cross Validation, and Active Learning", (Anders Krogh and Jesper Vedelsby, ADVANCES IN NEURAL INFORMATION PROCESSING SYSTEMS, 1995).

56 Through the sklearn.metrics package, we used the train_test_split package to split the entire dataset into an independent training and dependent training set batch of clusters that would later be used for training and accuracy evaluation, respectively.

57 See "Big Data Preprocessing: Methods and Prospects", (Salvador García, et al., BIG DATA ANALYTICS, 2016).

58 See "Probabilistic Neural Networks", (Donald F. Specht, NEURAL NETWORKS, 1990).
} 
by the Supreme Court Database, the algorithm could correctly predict $87.65 \%$ of the time whether the petitioner or respondent has or will win the case with a $75 \%$ confidence threshold.

\section{CONCLUSION}

Prior to our study, although biases ${ }^{59}$ could be perceived to be prevalent within the Supreme Court, the whole Supreme Court could not be generalized under the presumption that they only operate under their political parties. However, due to modern technologies' application to court, it has become easier to find the patterns in justice decisions and be able to see the bias effects and that Justices truly make their decisions based upon their political party bias rather enacting upon the constitution.

When personally asked prior to the study, Judge Kelvin D. Filer, Assistant Presiding Judge of the Compton Courthouse expected that "[we] will see consistencies" 60 and that these issues are "prevalent in our society". It has been noted in the past on the process of selection of Supreme Court Justices is based on their abilities as an attorney. Taking no account their political bias or their ability to be impartial. The methodology can be used in multiple ways for the future and the information given by the metric can be used to argue in court cases. The data provided from our analysis can be used by attorneys attempting to argue their case and understanding what influences judges. This methodology, using practical predictions, used to predict stock markets with regard to the Supreme Court's influence on the stock market.

The supreme court justices who have been largely unbiased and the most difficult to predict $^{61}$ namely, Justice Roberts and Kennedy deserve their recognition for the understanding that precedent-setting law is more important than the support of a political party. Accompanied by this, criticism must be drawn toward the justices who are increasingly easier to predict and completely partisan; which can be observed with Sotomayor and Ginsburg. This type of

\footnotetext{
${ }^{59}$ Opinion literature on Supreme Court ideological perspectives paint justices as cognizant of partisan biases, meanwhile acting upon said urges. Cit supra, note 22.

${ }^{60}$ We conducted preliminary interviews on the perspectives of judicial professionals on peers in the Supreme Court

${ }^{61}$ Cit. supra. Notes 9, 12, 13.
} 
partisanship is not what the Supreme Court is meant to represent; rather it is meant to represent the Constitution which our founding fathers had drawn out years ago to represent a free country.

Data de Submissão: 06/06/2019

Data de Aceite: 02/12/2019 